$$
\begin{aligned}
& \text { 바다송사리 Oryzias dancena와 자바송사리 } \\
& \text { Oryzias javanicus 간 잡종 유도 } \\
& \text { 송하연 }{ }^{1} \cdot \text { 남윤 권 }^{1,2} \cdot \text { 방인 철 }^{3} \cdot \text { 김 동수 }^{1,2 *} \\
& { }^{1} \text { 부경대학교 해양용 LMO 위해성 평가 센터, }{ }^{2} \text { 부경대학교 해양바이오신소재학과, } \\
& { }^{3} \text { 순천향대학교 해양생명공학과 }
\end{aligned}
$$

\title{
Hybridization between Marine Medaka Oryzias dancena and Javanese Medaka Oryzias javanicus
}

\author{
Ha Yeun Song', Yoon Kwon Nam ${ }^{1,2}$, In-Chul Bang ${ }^{3}$ \\ and Dong Soo $\mathrm{Kim}^{1,2, *}$ \\ ${ }^{1}$ Risk Assessment Center of Marine Living Modified Organisms, Pukyong National University, \\ Busan 608-737, Korea \\ ${ }^{2}$ Department of Marine Bio-Materials \& Aquaculture, Pukyong National University, \\ Busan 608-737, Korea \\ ${ }^{3}$ Department of Marine Biotechnology, Soonchunhyang University, Asan 336-745, Korea
}

Inductions of hybrids and reciprocal hybrids between Oryzias dancena and O. javanicus (ODJ and OJD) were conducted and backcross hybrids between female $O$. dancena and male ODJ were also produced for biological and cytogenetic analysis. Embryonic development of ODJ and OJD were compared with those of their parents. Developmental time was fastest in $O$. dancena and ODJ, followed by $O$. javanicus and OJD. Oryzias dancena hatched 11 days (d) after fertilization, ODJ at $13 \mathrm{~d}$, O. javanicus at $14 \mathrm{~d}$ and OJD at $15 \mathrm{~d}$. The abnormality of external morphology rate in ODJ was 10.6\%; however, OJD showed a high degree of abnormality, over $90 \%$. The proportion of males was $90.0 \%$ and $31.3 \%$ for ODJ and OJD, respectively. Cytogenetic analysis was conducted to obtain basic information for genetic identification of $O$. dancena, $O$. javanicus and their hybrids. The karyotypes of all experimental groups showed $2 \mathrm{n}=48$ chromosomes and the fundamental number (FN) was 48. The first pair carried secondary constrictions near the centromeric regions. Erythrocyte area and volume were $9.8 \pm 0.5 \mu^{2}$ and $18.2 \pm 1.0 \mu^{3}$, respectively, for $O$. dancena, $8.3 \pm 0.5 \mu^{2}$ and $15.8 \pm 1.5 \mu^{3}$ in $O$. javanicus, and $18.3 \pm 0.5 \mu^{2}$ and $15.7 \pm 1.3 \mathrm{\mu m}^{3}$ in ODJ. Erythrocyte area and volume in ODJ were similar to those of $O$. javanicus. In backcross hybrids between female $O$. dancena and male ODJ, all embryos failed to develop and died in the late gastrula stage.

Key words: Biological analysis, Cytogenetic analysis, Hybrid, Oryzias dancena, Oryzias javanicus

$$
\text { 서 론 }
$$

송사리는 동갈치목 (Beloniformes) 송사리과 (Adrianichthyidae) 에 속하는 경골어류로 Oryzias 속에는 전 세계 22종이 서식하 고 있다 (Robert, 1998; Nelson, 2006).

본 연구에 사용된 바다송사리 Oryzias dancena는 파키스탄, 인도, 미얀마, 방글라데시 및 태국 등지에 넓게 분포하고 있으 며, 자바송사리 O.javanicus는 싱가포르, 말레이 반도 및 태국 등지의 해변에 서식하고 있다 (Robert, 1998). 두 종 모두 염분 에 대한 내성이 강해 삼투압 조절 메커니즘 (Cho et al., 2010; Inoue and Takei, 2003)의 연구에 많이 이용되어 왔으며, 성결 정 기작 (Takehana et al., 2007a), 성분화 (Song et al., 2009a; Kakuno et al., 2001), 난발생 (Song et al., 2009b; Iwamatsu and Hirata, 1984) 그리고 분류·계통학적 연구 (Takehana et al., 2005) 등에 관한 연구결과들이 보고된 바 있다.

\footnotetext{
*Corresponding author: dongskim@pknu.ac.kr
}

어류에서 종간 잡종의 유도는 종의 분류학적 위치를 규명하 기 위한 연구 (Susuki and Hibiya, 1984; Kim and Kim, 1993) 이외에도 산업적으로 우량 형질을 가진 서로 다른 두 종간의 교잡을 통해 생산된 잡종의 잡종강세를 획득하기 위해서 이루 어지고 있으며 (Kim et al., 1995a; 1995b; Park et al., 1996; $\mathrm{Li}$ et al., 2006), 단성 집단을 생산하거나 유도된 잡종의 불임성 개체 생산을 위해 이루어지고 있다 (Park et al., 1996; 2003). Oryzias 속에 속하는 종들의 잡종 유도 연구는 이전부터 활발 히 이루어져 왔으나 (Hori and Iwamatsu, 1996; Iwamatsu et al., 1994; 1986; 1984; Kim and Kim, 1993), 대부분의 연구가 분류학적 위치를 규명하기 위하여 이루어져 왔으며, 최근에는 종간 잡종 연구를 통하여 잡종 개체의 염색체 배열 매커니즘 을 세포학적 및 분자생물학적으로 연구하기 위한 자료로도 활용되고 있다 (Sakai et al., 2007; Iwamatsu et al., 2003).

본 연구는 해양생태계위해성 평가를 위한 어류 모델을 개발 함에 있어 실험 어류가 생태계로 유입시 혼란을 야기할 가능 
성을 줄이기 위해 잡종 유도를 통한 불임 개체군을 생산하여 그 잡종 개체의 이용 가능성과 생물학적 특징을 조사하기 위하여 수행하였다. 이를 위해 바다송사리와 자바송사리의 잡종을 유도, 수정률, 부화율 및 기형률을 조사하였으며, 적혈 구의 세포와 핵의 크기 분석 및 NORs (nucleolar organizer regions) 분석과 염색체 수 및 핵형을 분석하였다. 또한, 바다송 사리 암컷과 잡종군 (바다송사리 우 $\times$ 자바송사리 $\sigma^{x}$ ) 수컷의 교배를 통하여 역교배체를 유도한 후 수정률과 난발생 과정을 관찰하였다.

\section{재료 및 방법}

실험어의 확보 및 사육 유지

본 실험에 사용된 바다송사리는 인도네시아로부터 자연산 (wild-type) 개체들을 수산동식물 이식승인에 관한 규칙에 의 거 (농림수산식품부령 제1호)하여 수입하였으며, 실험실에서 6 개월간 사육하여 친어로 사용하였다. 자바송사리는 한국해 양연구원 $(\mathrm{KORDI})$ 에서 암컷 5 개체와 수컷 3 개체를 분양받아 실험실 내에서 교배시켜 부화 시킨 자어를 6 개월간 사육하며 사용하였다. 사육수는 해수와 담수를 $5 \mu \mathrm{m}$ 의 미세필터로 여 과한 후 염분측정기를 이용하여 $10 \mathrm{psu}$ 기수를 제조하여 사용 하였으며 $20 \mathrm{~L}$ 의 유리수조에서 $25 \pm 1^{\circ} \mathrm{C}$ 로 유지하면서 광주기 (16L:8D)를 조절하였다. 매일 $1 / 2$ 씩 환수하였으며, 사료는 초 기미립자사료(이화사료 $150 \mu \mathrm{m}, 350 \mu \mathrm{m}$ 및 $500 \mu \mathrm{m}$ )와 brine shrimp 유생을 공급하였다. 정상 교배와 종간 잡종, 상반 잡종 및 역교배를 나타내는 기호는 Table 1 과 같다.

Table 1. Genotype abbreviations

\begin{tabular}{|c|c|}
\hline Species & Breeding \\
\hline OD & Oryzias dancena $+\underset{x}{ }$ O. dancena $\sigma^{7}$ \\
\hline OJ & Oryzias javanicus + × O. javanicus $\sigma^{7}$ \\
\hline ODJ & Oryzias dancena $ᄋ \times 0$. javanicus $\sigma^{7}$ \\
\hline OJD & Oryzias javanicus + × O. dancena $\sigma^{7}$ \\
\hline ODDJ & Oryzias dancena $q \times$ ODJ $\sigma^{x}$ \\
\hline
\end{tabular}

바다송사리와 자바송사리 간의 잡종, 상반 잡종 및 역교배체 유도

바다송사리, 자바송사리와 그들의 잡종 및 상반잡종의 수 정란을 확보하기 위하여 각 실험군 당 암컷 12마리와 수컷 8 마리씩을 교배시켜 산란을 유도하였다. 사용한 바다송사리 의 평균 전장은 암컷의 경우 $37.7 \pm 2.8 \mathrm{~mm}$ 였으며, 수컷은 $39.0 \pm 3.1 \mathrm{~mm}$ 였고, 자바송사리의 암컷은 $34.0 \pm 3.1 \mathrm{~mm}$, 수컷은 $34.9 \pm 4.3 \mathrm{~mm}$ 였다. 역교배체를 확보하기 위해서는 바다송사리 암컷 60 마리와 ODJ 중 형태학적으로 수컷 형질을 가진 개체 20 마리의 교배를 유도하였다.

\section{수정란의 수집과 난발생 관찰}

바다송사리와 자바송사리 그리고 잡종군들의 난발생 과정 을 관찰하기 위하여 산란한 직후 실험군의 암컷 개체에서
수정란을 분리하여 개체별 수정란을 $25 \pm 1{ }^{\circ} \mathrm{C}$ 의 $20 \mathrm{~L}$ 항온 부화수조 안에 설치한 부화망 (망목: $330 \times 330 \mu \mathrm{m}$, 크기: $12 \times 5 \times 5 \mathrm{~cm})$ 으로 옮겨 관찰하였다. 수정란은 광학현미경 (Nikon, Japan)과 해부현미경 (Olympus, Japan)으로 부화시기 까지 관찰하면서 수정된 개체의 $90 \%$ 이상이 동일한 단계에 도달하였을 때를 기준으로 각 단계별 발생과정과 시간을 기록 하였다. 바다송사리와 자바송사리의 최초 산란시기를 알아보 기 위하여 각 실험군 당 암컷 20마리와 수컷 12 마리를 함께 사육하며 산란 여부를 관찰하였다. 역교배체 (ODDJ)의 수정 란 조사를 위하여 수정란을 분리하여 $25 \pm 1{ }^{\circ} \mathrm{C}$ 의 $20 \mathrm{~L}$ 항온 부화수조로 옮긴 후 광학현미경에서 초기 난발생을 13회 산란 으로 조사하였으며, 발생 단계별 과정을 현미경에 부착된 디 지털 카메라 (ARTRAY, Japan)로 촬영하고 관찰하였다.

\section{수정률, 부화율 및 기형률 측정}

바다송사리, 자바송사리 및 잡종군 $(\mathrm{ODJ}, \mathrm{OJD})$ 의 수정률은 전체 수정난 중 흰색으로 변한 죽은 알의 수를 제외하고 발생 이 진행 중인 난수를 백분율로 나타내었다. 기형률은 Iwamatsu et al. (1986)가 보고한 바 있는 척추 만곡 (wavy vertebral column) 개체를 대상으로 계수하였으며, 부화율과 기형률은 전체 수정난에 대한 부화 개체수와 기형 개체수의 백분율로 측정하였다.

\section{성장 조사}

바다송사리, 자바송사리 및 잡종군 (ODJ)에서 부화한 자어 는 친어 사육 조건과 동일한 조건에서 사육하였다. 성장을 조사하기 위하여 부화 직후 부화 후 6일째까지 매일, 그리고 부화 후 9일, 14일, 21일, 28일째, 6주와 9주째에 12마리씩을 무작위로 선별하여 얼음에 마취한 후, 전장 (total length)을 버어니어 캘리퍼스로 $0.01 \mathrm{~mm}$ 까지 측정하였다.

\section{적혈구 계측 및 $\mathrm{NORs}$ 분석}

적혈구 세포 및 핵의 크기를 측정하기 위해 바다송사리, 자바송사리와 그들의 잡종군인 ODJ 개체 암.수를 각각 6마리 씩 추출하여 사용하였다. 각 개체 당 100 개 이상의 적혈구를 측정하였으며, 적혈구 세포 및 핵의 장경과 단경을 광학현미 경하에서 micrometer를 사용하여 400배의 배율로 측정하였다. 표면적은 장경 (a)·(b)· $\pi / 4$ (Sezaki and Kobayashi, 1978), 부피 는 $4(\mathrm{a} / 2) \cdot(\mathrm{b} / 2)^{2} \cdot \pi / 3$ (Lemoine and Smith, 1980 )의 공식에 의하 여 계산하였다.

적혈구의 NORs을 분석하기 위하여 바다송사리와 자바송 사리에서 암수 각각 5마리를 택해 적혈구를 슬라이드에 도말 한 후 $2 \%$ gelatin 용액 (gelatin solution in $1 \%$ formic acid) $300 \mu \mathrm{l}$ 와 $50 \%$ silver nitrate 용액 $\left(\mathrm{AgNO}_{3}\right) 150 \mu \mathrm{l}$ 를 잘 혼합하 여, $57^{\circ} \mathrm{C}$ 로 맞추어진 슬라이드 건조기에서 70 초간 발색 반응 을 수행하였다. 반응이 완료된 후 광학현미경으로 NORs 수를 관찰(1,000배) 하였다.

염색체 수 및 핵형 분석

염색체 수 판별 및 핵형분석을 위하여 신장직접법 $(\mathrm{Kim}$ et al., 1982)을 사용하였다. 바다송사리, 자바송사리와 그들의 
잡종군인 $\mathrm{ODJ}$ 와 OJD를 무작위로 20마리씩 선별하여 슬라이 드 표본을 제작하여 염색체 중기 분열상을 대상으로 계수하였 다. 분열상이 뚜렷한 시료를 대상으로 광학현미경에 부착된 디지털 카메라로 사진 촬영하여 핵형도를 작성하였다.

\section{성비(sex ratio) 조사}

유도된 잡종과 대조군의 성비를 조사하기 위하여 부화 후 12 주째 개체를 무작위로 20 마리씩 3반복으로 표본 채집하여 뒷지느러미 형태로 성비를 조사하였으며, 형태학적으로 암수 를 분리한 잡종과 대조군에서 바다송사리, 자바송사리 그리고 $\mathrm{ODJ}$ 는 암.수 각각 15 마리씩, $\mathrm{OJD}$ 는 8 마리씩을 무작위로 표본 추출하여 머리와 항문 이후의 꼬리 부분을 제거한 몸통 부분 을 Bouin's 용액에 고정한 후 평상의 paraffin 절편법으로 8 $\mu \mathrm{m}$ 두께로 절편하였다. 염색은 Harris's hematoxylin과 eosin 으로 하였으며, 광학현미경 (Nikon, Japan) 하에서 성비를 관찰 하였다.

\section{통계 처리}

수정률, 부화율 및 기형률은 유의차 검정을 하기 위하여 $P<0.05$ 수준에서 ANOVA 검정을 하였으며 성비 분석은 $\chi^{2}$ test를 하였다.

$$
\text { 결 과 }
$$

난발생 과정

난발생 과정 및 발육단계에 따른 자치어의 형태 발달 시간 은 Table 2에 나타내었다. 바다송사리와 자바송사리의 경우 배반이 형성되는 시기는 수정 후 1시간째로 동일하였으나, 2세포기부터 자바송사리의 발생 속도가 느려지기 시작해 심 장 박동 시기에 이르는 시간은 바다송사리에 비해 늦어지기 시작하였다. ODJ와 $\mathrm{OJD}$ 의 난발생 과정을 친어로 사용된 바다 송사리와 자바송사리와의 난발생 시간과 비교한 결과 심장 기관 형성 단계까지의 시간은 바다송사리와 ODJ의 발생 속도 가 유사하였으나, 그 이후 단계인 심장 박동기부터 ODJ가 바다송사리 보다 느려졌다. 자바송사리와 $\mathrm{OJD}$ 는 후기 낭배기 까지는 발생 속도가 유사하였으나, 그 이후 단계부터 $\mathrm{OJD}$ 의 발생 속도가 느려지기 시작하였다. 발생 속도는 바다송사리가 가장 빨랐으며, 다음으로 $\mathrm{ODJ}$, 자바송사리 그리고 $\mathrm{OJD}$ 의 순 이었다. 부화 시간의 순서 역시 발생속도와 동일하였으며, 바다송사리가 수정 후 11 일째에, 자바송사리가 14일, ODJ 가 13 일째에 부화하였으며, OJD가 가장 느린 수정 후 15 일째 에 부화하였다.

Table 2. Characteristics of egg development in Oryzias dancena (OD), O. javanicus (OJ) and interspecific hybrids between Oryzias dancena and O. javanicus (ODJ \& OJD)

\begin{tabular}{|c|c|c|c|c|}
\hline \multirow{2}{*}{ Developmental stage } & \multicolumn{4}{|c|}{ Time (after fertilization) } \\
\hline & OD & OJ & ODJ & OJD \\
\hline Fertilized eggs & $00 \mathrm{hr}$ & $00 \mathrm{hr}$ & $00 \mathrm{hr}$ & $00 \mathrm{hr}$ \\
\hline Blastodisc stage & $01 \mathrm{hr}$ & $01 \mathrm{hr}$ & $01 \mathrm{hr}$ & $01 \mathrm{hr}$ \\
\hline Two cells stage & $01 \mathrm{hr} 30 \mathrm{~min}$ & $01 \mathrm{hr} 45 \mathrm{~min}$ & $01 \mathrm{hr} 30 \mathrm{~min}$ & $01 \mathrm{hr} 45 \mathrm{~min}$ \\
\hline Four cells stage & $02 \mathrm{hr} 05 \mathrm{~min}$ & $02 \mathrm{hr} 30 \mathrm{~min}$ & $02 \mathrm{hr} 05 \mathrm{~min}$ & $02 \mathrm{hr} 30 \mathrm{~min}$ \\
\hline Eight cells stage & $03 \mathrm{hr}$ & $03 \mathrm{hr} 15 \mathrm{~min}$ & $03 \mathrm{hr}$ & $03 \mathrm{hr} 15 \mathrm{~min}$ \\
\hline Sixteen cells stage & $03 \mathrm{hr} 30 \mathrm{~min}$ & $03 \mathrm{hr} 45 \mathrm{~min}$ & $03 \mathrm{hr} 30 \mathrm{~min}$ & $03 \mathrm{hr} 45 \mathrm{~min}$ \\
\hline Thirty-two cells stage & $04 \mathrm{hr} 30 \mathrm{~min}$ & $05 \mathrm{hr}$ & $04 \mathrm{hr} 30 \mathrm{~min}$ & $05 \mathrm{hr}$ \\
\hline Morula stage & $05 \mathrm{hr} 30 \mathrm{~min}$ & $06 \mathrm{hr} 15 \mathrm{~min}$ & $05 \mathrm{hr} 30 \mathrm{~min}$ & $06 \mathrm{hr} 15 \mathrm{~min}$ \\
\hline Blastula stage & $07 \mathrm{hr} 45 \mathrm{~min}$ & $08 \mathrm{hr} 45 \mathrm{~min}$ & $07 \mathrm{hr} 45 \mathrm{~min}$ & $08 \mathrm{hr} 45 \mathrm{~min}$ \\
\hline Early gastrula stage & $13 \mathrm{hr} 10 \mathrm{~min}$ & $14 \mathrm{hr} 30 \mathrm{~min}$ & $13 \mathrm{hr} 10 \mathrm{~min}$ & $14 \mathrm{hr} 30 \mathrm{~min}$ \\
\hline Mid gastrula stage & $16 \mathrm{hr} 45 \mathrm{~min}$ & $17 \mathrm{hr}$ & $16 \mathrm{hr} 45 \mathrm{~min}$ & $17 \mathrm{hr}$ \\
\hline Late gastrula stage & $21 \mathrm{hr} 30 \mathrm{~min}$ & $22 \mathrm{hr} 30 \mathrm{~min}$ & $21 \mathrm{hr} 30 \mathrm{~min}$ & $22 \mathrm{hr} 30 \mathrm{~min}$ \\
\hline Early neurula stage & $1 \mathrm{~d} 06 \mathrm{hr}$ & $1 \mathrm{~d} 06 \mathrm{hr} 30 \mathrm{~min}$ & $1 \mathrm{~d} 06 \mathrm{hr}$ & $1 \mathrm{~d} 07 \mathrm{hr}$ \\
\hline Late neurula stage & $1 \mathrm{~d} 07 \mathrm{hr}$ & $1 \mathrm{~d} 08 \mathrm{hr}$ & $1 \mathrm{~d} 07 \mathrm{hr}$ & $1 \mathrm{~d} 08 \mathrm{hr} 30 \mathrm{~min}$ \\
\hline 2 somite stage & $1 \mathrm{~d} 08 \mathrm{hr} 30 \mathrm{~min}$ & $1 \mathrm{~d} 09 \mathrm{hr}$ & $1 \mathrm{~d} 08 \mathrm{hr} 30 \mathrm{~min}$ & $1 \mathrm{~d} 09 \mathrm{hr} 30 \mathrm{~min}$ \\
\hline 4 somite stage & $1 \mathrm{~d} 11 \mathrm{hr}$ & $1 \mathrm{~d} 11 \mathrm{hr} 30 \mathrm{~min}$ & $1 \mathrm{~d} 11 \mathrm{hr}$ & $1 \mathrm{~d} 13 \mathrm{hr}$ \\
\hline 6 somite stage & $1 \mathrm{~d} 13 \mathrm{hr}$ & $1 \mathrm{~d} 15 \mathrm{hr}$ & $1 \mathrm{~d} 13 \mathrm{hr}$ & $1 \mathrm{~d} 15 \mathrm{hr} 30 \mathrm{~min}$ \\
\hline 9 somite stage & $1 \mathrm{~d} 22 \mathrm{hr}$ & $2 \mathrm{~d} 01 \mathrm{hr}$ & $1 \mathrm{~d} 22 \mathrm{hr}$ & $2 \mathrm{~d} 02 \mathrm{hr}$ \\
\hline Formation of tubular heart & 2 d 01 hr $30 \mathrm{~min}$ & $2 \mathrm{~d} 03 \mathrm{hr}$ & $2 \mathrm{~d} 01 \mathrm{hr} 30 \mathrm{~min}$ & $2 \mathrm{~d} 03 \mathrm{hr}$ \\
\hline Start of heart beating & $2 \mathrm{~d} 04 \mathrm{hr}$ & $2 \mathrm{~d} 06 \mathrm{hr}$ & $2 \mathrm{~d} 05 \mathrm{hr} 30 \mathrm{~min}$ & $2 \mathrm{~d} 07 \mathrm{hr}$ \\
\hline Onset of blood circulation & $2 \mathrm{~d} 14 \mathrm{hr}$ & $2 \mathrm{~d} 22 \mathrm{hr}$ & $2 \mathrm{~d} 23 \mathrm{hr}$ & $3 \mathrm{~d} 00 \mathrm{hr}$ \\
\hline $\begin{array}{l}\text { Onset of retinal } \\
\text { pigmentation }\end{array}$ & $4 \mathrm{~d} 00 \mathrm{hr}$ & $4 \mathrm{~d} 08 \mathrm{hr}$ & $4 \mathrm{~d} 06 \mathrm{hr}$ & $4 \mathrm{~d} 10 \mathrm{hr}$ \\
\hline Gill blood vessel formation & $4 \mathrm{~d} 18 \mathrm{hr}$ & $5 \mathrm{~d} 00 \mathrm{hr}$ & $4 \mathrm{~d} 23 \mathrm{hr}$ & $6 \mathrm{~d} 00 \mathrm{hr}$ \\
\hline $\begin{array}{c}\text { Formation of visceral blood } \\
\text { vessel }\end{array}$ & $6 \mathrm{~d} 16 \mathrm{hr}$ & $8 \mathrm{~d} 00 \mathrm{hr}$ & $7 \mathrm{~d} 06 \mathrm{hr}$ & $8 \mathrm{~d} 06 \mathrm{hr}$ \\
\hline $\begin{array}{c}\text { Heart and spleen } \\
\text { development }\end{array}$ & $8 \mathrm{~d}$ & $11 \mathrm{~d}$ & $10 \mathrm{~d}$ & $12 \mathrm{~d}$ \\
\hline Just hatched larvae & $11 \mathrm{~d}$ & $14 \mathrm{~d}$ & $13 \mathrm{~d}$ & $15 \mathrm{~d}$ \\
\hline First ovulation stage & $65 \mathrm{~d}$ & $93 \mathrm{~d}$ & - & - \\
\hline
\end{tabular}

d, day; hr, hour; min, minute. 
Table 3. Percent fertilization, hatching and abnoramlity in Oryzias dancena (OD), O. javanicus (OJ) and interspecific hybrids between $O$. dancena and $O$. javanicus

\begin{tabular}{|c|c|c|c|c|}
\hline Exp-group & $\begin{array}{l}\text { No. of eggs } \\
\text { used (females) }\end{array}$ & $\begin{array}{c}\text { Fertilization } \\
\text { rate }(\%)\end{array}$ & Hatching $(\%)$ & $\begin{array}{c}\text { Abnormality } \\
\text { rate }(\%)\end{array}$ \\
\hline 101 & $1934(53)$ & $97.3 \pm 0.6^{a}$ & & $0.7 \pm 0$ \\
\hline OJ (ㅇ) x OJ (万) & $573(62)$ & $92.3 \pm 2.4^{\mathrm{b}}$ & $80.3 \pm 2.8^{\mathrm{b}}$ & $0.8 \pm 1.0^{a}$ \\
\hline $\mathrm{OD}$ (우) xOJ (ðౌ) & $488(2$ & & & \\
\hline $\mathrm{OJ}$ (ㅇ) X OD (주) & $477(55)$ & $81.8 \pm 2.6^{d}$ & $7.4 \pm 1.1^{c}$ & $90.5 \pm 13$ \\
\hline
\end{tabular}

1 Means with different superscripst within a column are significantly different $(P<0.05)$, based on ANOVA test. Values are mean $\pm \mathrm{SD}$.

수정률, 부화율 및 기형률 조사

바다송사리, 자바송사리 및 유도된 잡종의 수정률, 부화율 및 기형률을 Table 3에 나타내었다. 친어군인 바다송사리(97.3 $\pm 0.6 \%)$ 와 자바송사리 $(92.3 \pm 2.4 \%)$ 의 평균 수정률에 비해 잡종군인 $\mathrm{ODJ}(89.4 \pm 2.7 \%)$ 와 OJD $(81.8 \pm 2.6 \%)$ 의 수정률이 다소 낮았다. 부화율은 바다송사리 $(93.4 \pm 2.7 \%)$ 와 자바송사 리 $(80.3 \pm 2.8 \%)$ 보다 ODJ $(80.2 \pm 2.3 \%)$ 가 낮게 나타났으며, $\mathrm{OJD}$ 의 경우 부화율이 $7.4 \pm 1.1 \%$ 로 다른 실험군들보다 현저히 낮은 부화율을 보였다. 기형률에 있어서 ODJ $(10.6 \pm 2.3 \%)$ 가 친어군인 바다송사리 $(0.7 \pm 0.8 \%)$ 와 자바송사리 $(0.8 \pm 1.0 \%)$ 보다 높게 나타났으며, $\mathrm{OJD}$ 의 기형률은 $90.5 \pm 13.1 \%$ 로 현저 히 높은 기형률을 나타냈다 (Fig. 1).

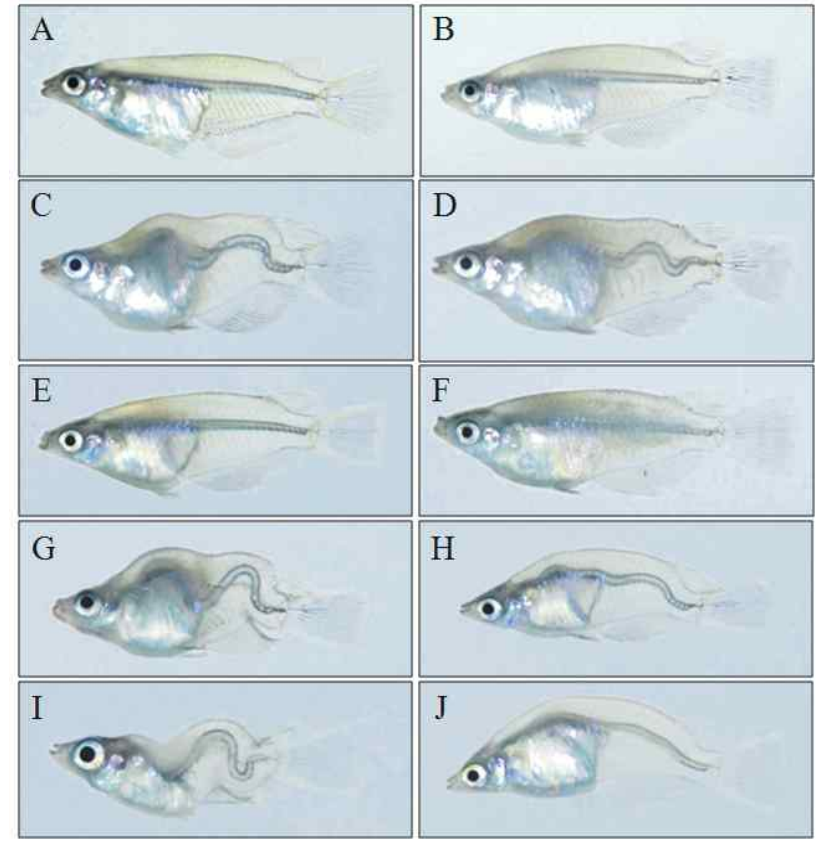

Fig. 1. External morphology of hybrid of between $O$. dancena and $O$. javanicus. A - D: O. dancena ( $($ ) and $O$. javanicus $\left(\mathrm{O}^{7}\right)$ hybird (ODJ). (A) ODJ female (B) ODJ male (C, D) Abnormal ODJ. E - F: O. javanicus (O ) and O. dancena $\left(\sigma^{x}\right)$ hybird (OJD). (E) OJD female. (F) OJD male. (G J) Abnormal OJD.

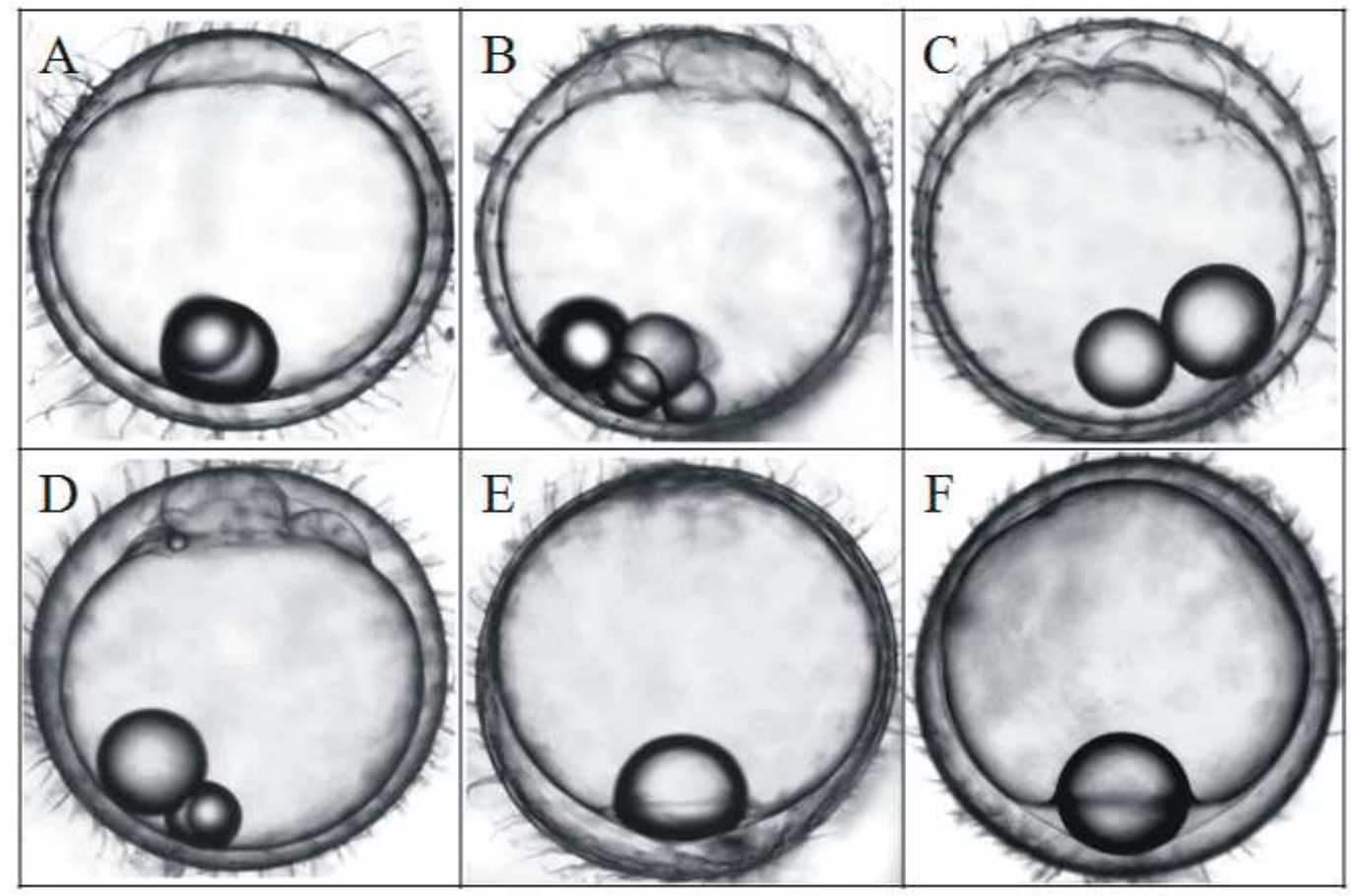

Fig. 2. Egg development of Oryzias dancena and ODJ (O. dancena x O. javanicus), OD x ODJ (water temperature: 25 $\pm 1{ }^{\circ} \mathrm{C}$ ). (A) Blastodisc at 5 hours after fertilization, (B) 2 cells stage at 7-9 hours after fertilization, (C, D) Abnormally developing eggs between 7 hours and 40 hours after fertilization, (E) Late gastrula stage at 40 hours after fertilization, (F) Late gastrula stage at 3 days after fertilization. 
Table 4. Fertilization rates, late gastrula rates and hatching rates of ODDJ produced from crossed with female Oryzias dancena and male $O$. dancena x O. javanicus (ODJ)

\begin{tabular}{cccc}
\hline $\begin{array}{c}\text { No. of eggs } \\
\text { spawned }\end{array}$ & $\begin{array}{c}\text { Fertilization rate } \\
(\%)\end{array}$ & $\begin{array}{c}\text { Survival rate } \\
(\%)^{* *}\end{array}$ & $\begin{array}{c}\text { Hatching rate } \\
(\%)\end{array}$ \\
\hline 3,006 & $36.2 \pm 18.0^{*}$ & $4.3 \pm 2.6^{*}$ & 0
\end{tabular}

$*$ mean $\pm \mathrm{SD}$.

**Live eggs at late gastrula stage.

역교배체 (ODDJ)의 수정률, 초기 난발생 및 부화율 역교배체 유도를 위하여 바다송사리 암컷과 ODJ 수컷의 교배를 통해 유도된 ODDJ의 수정률과 부화율을 측정한 결과 는 Table 4에 나타내었으며, 초기 난발생과 발생과정에 따른 형태적 변화를 측정한 결과는 Fig. 2에 나타내었다. 수정 후 2시간째에 유구가 식물극 쪽으로 이동하기 시작하고, 수정 후 5시간이 지난 1 세포기가 되었다 (Fig. 2A). 2세포기에 도달 하는 시간은 수정 후 7시간부터 9시간 까지 다양하게 나타났 으며, 세포 형태 또한 서로 크기가 다르게 나타났다 (Fig. 2B). 후기 낭배기 (late gastrula)가 나타나는 수정 후 40시간까지 수정난의 생존율은 $4.3 \pm 2.6 \%$ 로 대부분이 발생도중 폐사하였 으며, 분열하는 세포 형태는 불규칙한 형태를 나타내었다 (Fig. 2C, 2D). 수정 후 3일째까지 후기 낭배기에서 더 이상 발생이 진행되지 않고 그대로 유지되다가 (Fig. 2E, 2F) 모든 수정난이 폐사하였다.

\section{성장 조사}

바다송사리, 자바송사리와 ODJ의 부화 직후부터 9주까지 의 전장은 Table 5와 Fig. 3 에 나타내었다. 부화 직후 치어의 길이는 ODJ가 $4.3 \pm 0.4 \mathrm{~mm}$ 로 ANOVA test 결과 자바송사리 $(5.0 \pm 0.2 \mathrm{~mm})$ 보다 모계인 바다송사리 $(4.4 \pm 0.3 \mathrm{~mm})$ 와 유사 하였다. 부화 후 28 일째부터 바다송사리의 성장이 급속히 증 가하여, 부화 후 9주째에 바다송사리가 다른 실험군들 보다

Table 5. Growth in total length of Oryzias dancena (OD), $O$. javanicus $(\mathrm{OJ})$ and interspecific hybrids between $O$. dancena and $O$. javanicus (ODJ)

\begin{tabular}{cccc}
\hline \multirow{2}{*}{ Age } & \multicolumn{3}{c}{ Total length $(\mathrm{mm})^{*}$} \\
\cline { 2 - 4 } & OD & OJ & ODJ \\
\hline $0 \mathrm{~d}$ & $4.4 \pm 0.3$ & $5.0 \pm 0.2$ & $4.3 \pm 0.4$ \\
$1 \mathrm{~d}$ & $4.4 \pm 0.5$ & $5.2 \pm 0.2$ & $4.5 \pm 0.3$ \\
$2 \mathrm{~d}$ & $4.5 \pm 0.1$ & $5.2 \pm 0.2$ & $4.6 \pm 0.1$ \\
$3 \mathrm{~d}$ & $4.6 \pm 0.2$ & $5.5 \pm 0.3$ & $5.1 \pm 0.2$ \\
$4 \mathrm{~d}$ & $4.6 \pm 0.5$ & $5.6 \pm 0.3$ & $5.2 \pm 1.6$ \\
$5 \mathrm{~d}$ & $4.7 \pm 0.3$ & $6.7 \pm 0.2$ & $5.3 \pm 0.2$ \\
$6 \mathrm{~d}$ & $4.7 \pm 0.4$ & $7.5 \pm 0.3$ & $5.4 \pm 0.3$ \\
$9 \mathrm{~d}$ & $5.2 \pm 0.5$ & $8.7 \pm 0.4$ & $7.0 \pm 0.6$ \\
$14 \mathrm{~d}$ & $7.2 \pm 0.8$ & $10.0 \pm 0.5$ & $8.2 \pm 0.5$ \\
$3 \mathrm{w}$ & $8.6 \pm 0.5$ & $10.7 \pm 0.3$ & $10.8 \pm 1.3$ \\
$4 \mathrm{w}$ & $12.8 \pm 1.1$ & $12.5 \pm 0.7$ & $12.8 \pm 0.8$ \\
$6 \mathrm{w}$ & $18.5 \pm 1.8$ & $17.0 \pm 0.9$ & $18.2 \pm 0.8$ \\
$9 \mathrm{w}$ & $22.5 \pm 2.3$ & $21.5 \pm 0.7$ & $21.5 \pm 1.1$ \\
\hline
\end{tabular}

* Mean \pm SD.

d, day; w, week.

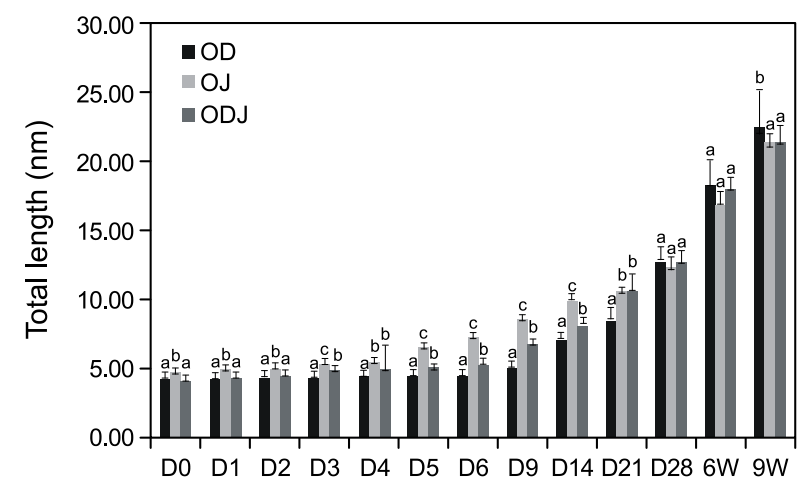

Fig. 3. Comparisons of growth in total length of Oryzias dancena (OD), O. javanicus (OJ) and O. dancena ( $Q$ ) and $O$. javanicus $\left(O^{\prime}\right)$ hybrid (ODJ).

1 Means with different superscripst within a column are significantly different $(P<0.05)$, based on ANOVA test. Values are mean $\pm \mathrm{SD}$.

Table 6. Comparison of cell and nuclear sizes of Oryzias dancena (OD), O. javanicus (OJ) and hybrid of $O$. dancena and $O$. javanicus (ODJ)

\begin{tabular}{|c|c|c|c|c|}
\hline & Item & OD & OJ & ODJ \\
\hline \multirow{4}{*}{$\begin{array}{l}\text { Cell } \\
\text { size }\end{array}$} & Major axis $(\mu \mathrm{m})$ & $8.82 \pm 0.45^{\mathrm{a}}$ & $7.71 \pm 0.40^{b}$ & $7.81 \pm 0.20^{b}$ \\
\hline & Minor axis $(\mu \mathrm{m})$ & $7.60 \pm 0.37^{\mathrm{a}}$ & $6.59 \pm 0.55^{b}$ & $6.81 \pm 0.60^{b}$ \\
\hline & $\begin{array}{l}\text { Surface area } \\
\qquad\left(\mu \mathrm{m}^{2}\right)\end{array}$ & $52.57 \pm 1.22^{\mathrm{a}}$ & $41.73 \pm 1.11^{b}$ & $40.13 \pm 3.46^{b}$ \\
\hline & Volume $\left(\mu \mathrm{m}^{3}\right)$ & $266.21 \pm 10.95^{\mathrm{a}}$ & $189.34 \pm 11.29^{b}$ & $177.07 \pm 22.88^{b}$ \\
\hline \multirow{4}{*}{$\begin{array}{l}\text { Nuclear } \\
\text { sizes }\end{array}$} & Major axis $(\mu \mathrm{m})$ & $4.43 \pm 0.42^{\mathrm{a}}$ & $3.73 \pm 0.42^{\mathrm{b}}$ & $3.74 \pm 0.17^{b}$ \\
\hline & Minor axis $(\mu \mathrm{m})$ & $2.80 \pm 0.13^{\mathrm{a}}$ & $2.83 \pm 0.18^{\mathrm{a}}$ & $2.84 \pm 0.19^{\mathrm{a}}$ \\
\hline & $\begin{array}{c}\text { Surface area } \\
\left(\mu \mathrm{m}^{2}\right)\end{array}$ & $9.75 \pm 0.45^{\mathrm{a}}$ & $8.33 \pm 0.45^{b}$ & $8.30 \pm 0.50^{b}$ \\
\hline & Volume $\left(\mu \mathrm{m}^{3}\right)$ & $18.20 \pm 0.95^{\mathrm{a}}$ & $15.80 \pm 1.45^{\mathrm{a}}$ & $15.66 \pm 1.25^{\mathrm{a}}$ \\
\hline
\end{tabular}

* Means with different superscript letter in a same low are significantly different $(P<0.05)$. Values are mean \pm SD.

가장 성장이 빠른 것으로 나타났다 $(P<0.05)$. 최초 산란시기 역시 바다송사리가 부화 후 65일로, 자바송사리의 93일에 비 하여 빨리 나타났다.

\section{적혈구 세포 및 핵의 크기}

바다송사리와 자바송사리 그리고 잡종군인 $\mathrm{ODJ}$ 의 적혈구 세포 및 핵의 크기를 분석한 결과는 Table 6에 나타내었다. 바다송사리의 적혈구 세포의 표면적 및 부피는 각각 52.57 $\pm 1.22 \mu \mathrm{m}^{2}$ 및 $266.21 \pm 10.95 \mu \mathrm{m}^{3}$ 였고, 핵의 표면적 및 부피는 $9.75 \pm 0.45 \mu^{2}$ 및 $18.20 \pm 0.95 \mu^{3}$ 였다. 자바송사리의 적혈구 세포 표면적 및 부피는 $41.73 \pm 1.11 \mu \mathrm{m}^{2}$ 와 189.34 $\pm 11.29 \mu^{3}$ 였으며, 핵의 표면적은 $8.33 \pm 0.45 \mu \mathrm{m}^{2}$, 부피는 $15.80 \pm 1.45 \mu \mathrm{m}^{3}$ 로 바다송사리보다 세포와 핵의 크기가 모두 작게 나타났다. ODJ 적혈구의 세포 표면적 및 부피는 40.13 $\pm 3.46 \mu \mathrm{m}^{2}$ 와 $177.07 \pm 22.88 \mu \mathrm{m}^{3}$ 로 나타났고, 핵의 표면적은 $8.30 \pm 0.50 \mu^{2}$, 부피는 $15.66 \pm 1.25 \mu^{3}$ 로 나타나 부계인 자바송사리와 유사한 것으로 나타났다 $(P<0.05)$. 


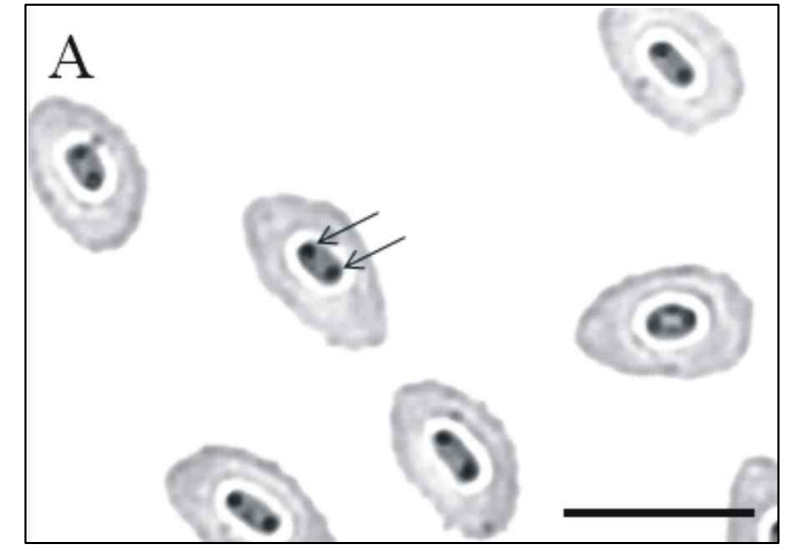

Fig. 4. Photographs of silver-stained erythrocytes of Oryzias dancena (A) and O. javanicus (B). Arrows indicate nuclear organisms regions (NORs). All scale bars indicate $10 \mu \mathrm{m}$.

Table 7. Chromosome counts of Oryzias dancena (OD), O. javanicus (OJ) and their hybrids (ODJ and OJD)

\begin{tabular}{|c|c|c|c|c|c|c|c|}
\hline \multirow{2}{*}{ Species ${ }^{*}$} & \multirow{2}{*}{$\begin{array}{c}\text { No. of } \\
\text { fish } \\
\text { examined }\end{array}$} & \multirow{2}{*}{$\begin{array}{l}\text { No. of } \\
\text { metaphase } \\
\text { counted }\end{array}$} & \multicolumn{5}{|c|}{$\begin{array}{c}\text { Frequency of chromosome } \\
\text { number }\end{array}$} \\
\hline & & & 46 & 47 & 48 & 49 & 50 \\
\hline OD & 17 & 100 & 13 & 14 & 67 & 5 & 1 \\
\hline OJ & 18 & 100 & 9 & 15 & 72 & 4 & 0 \\
\hline ODJ & 16 & 100 & 15 & 18 & 57 & 6 & 4 \\
\hline OJD & 18 & 100 & 12 & 17 & 63 & 6 & 2 \\
\hline
\end{tabular}

\section{적혈구의 NORs 분석}

바다송사리와 자바송사리 적혈구의 NORs을 분석한 결과 모두 세포 당 1 개와 2 개의 NORs이 나타났고, 그 빈도는 바다 송사리가 세포 당 1 개가 $20.5 \%, 2$ 개가 $78.0 \%$ 로 나타났고 (Fig. $4 \mathrm{~A})$, 자바송사리의 경우 세포 당 1 개가 $12.2 \%, 2$ 개가 $88.8 \%$ 로 나타났다 (Fig. 4B).

\section{염색체 수 및 핵형 분석}

바다송사리와 자바송사리 그리고 그들의 잡종군들인 $\mathrm{ODJ}$ 와 $\mathrm{OJD}$ 의 염색체수를 조사한 결과는 Table 7에 나타내었다. 바다송사리의 분석된 개체는 모두 $2 \mathrm{n}=48$ 로, 핵형은 차단부동 원체 (acrocentric) 염색체가 24쌍으로 나타났으며, fundamental number $(\mathrm{FN})$ 는 48 이었고, 차단부동원체 중 한 쌍에서 2차 수축 (secondary constriction)이 나타났다 (Fig. 5A). 자바송사리의 염색체수는 바다송사리와 동일하게 $2 \mathrm{n}=48$ 로 나타났으며, 1 쌍의 차간부염색체 (subtelocentric)와 23 쌍의 차단부동원체를 가지고 있었다. $\mathrm{FN}$ 은 48이었다. 두 종 모두에서 암.수간 염색 체수의 차이는 나타나지 않았고, heteromorphic한 염색체는 관찰할 수 없었다 (Fig. 5B). ODJ와 OJD의 modal 염색체 수는 각각 $2 n=48$ 이었고, 핵형은 24 쌍의 차단부동원체로 구성되어 있었으며 $\mathrm{FN}$ 은 48 이었다. 차단부동원체 중 한 쌍에서 2차 수축 이 관찰되었으며, 잡종군들에서도 암.수간 heteromorphic한 염

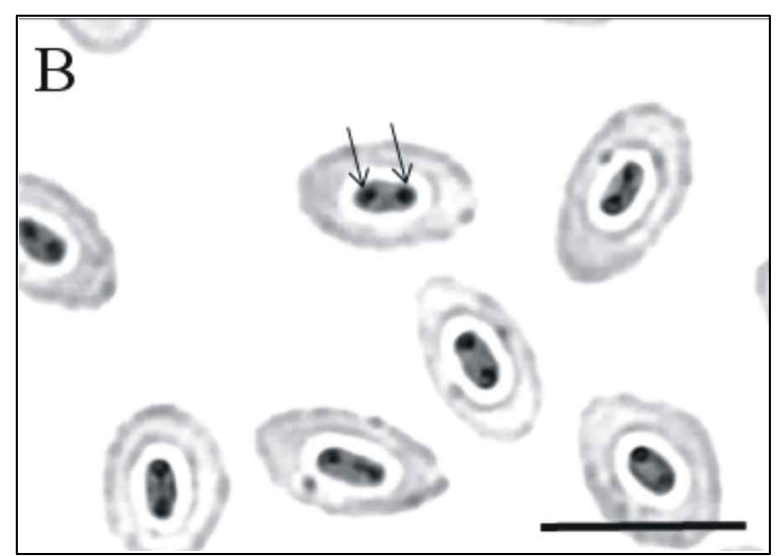

색체와 개체 간 염색체 다형 현상은 관찰되지 않았다 (Fig. 6A, 6B).

성비

뒷지느러미를 조사하여 암컷과 수컷의 성비를 조사한 결과 는 Table 8에 나타내었다. 바다송사리와 자바송사리 모두 암. 수의 성비가 거의 1 대 1 의 비율로 나타났으며, $\chi^{2}$ test 결과 바다송사리와 자바송사리 간의 암수 비율에 유의적인 차이가 나타나지 않았다. 유도된 잡종의 경우 ODJ는 암컷 $(26.7 \pm$ $5.8 \%)$ 보다 수컷 $(73.3 \pm 5.8 \%)$ 의 성비가 유의적으로 높게 나타 났으며, $\mathrm{OJD}$ 에서도 수컷 $(63.3 \pm 5.8 \%)$ 의 비율이 암컷 $(36.7$ $\pm 5.8 \%$ ) 보다 높게 나타났다. $\chi^{2}$ test 결과 ODJ는 수컷의 성비 가 유의적으로 높게 나타났으며, $\mathrm{OJD}$ 는 차이가 없는 것으로 나타났다.

조직학적 분석 결과는 Table 9에 나타내었다. 바다송사리와 자바송사리는 형태학적으로 구분된 암수의 결과가 조직학적 으로 조사한 결과와 일치하였다. ODJ의 경우 조직 검경 결과 형태학적 암컷 15 마리 중 13 마리가 수컷, 2 마리가 간성으로 1 마리만 암컷 생식소를 가지고 있었다. 형태학적 수컷인 개체 의 경우에는 모두 수컷 생식소를 가지고 있는 것으로 나타났 으며, 정원세포와 정세포는 많이 관찰되었으나, 정자부족증

Table 8. Sex ratios of Oryzias dancena (OD), O. javanicus (OJ) and their hybrids (ODJ and OJD) by sexual characteristic analysis of anal fin

\begin{tabular}{ccccc}
\hline Group & $\begin{array}{c}\text { No. of fish } \\
\text { analyzed }\end{array}$ & Female (\%) & Male (\%) & $\begin{array}{c}x^{2} \text { against }^{*} \\
1+1 \delta^{*}\end{array}$ \\
\hline OD & 60 & $53.3 \pm 7.6$ & $46.7 \pm 7.6$ & $\mathrm{~ns}$ \\
OJ & 60 & $48.3 \pm 7.6$ & $51.7 \pm 7.6$ & $\mathrm{~ns}$ \\
ODJ & 60 & $26.7 \pm 5.8$ & $73.3 \pm 5.8$ & $\mathrm{z}$ \\
OJD & 30 & $36.7 \pm 5.8$ & $63.3 \pm 5.8$ & $\mathrm{z}$ \\
\hline
\end{tabular}

* ns: not significant, $\mathrm{z}: P<0.005$.

Values are mean \pm SD. 


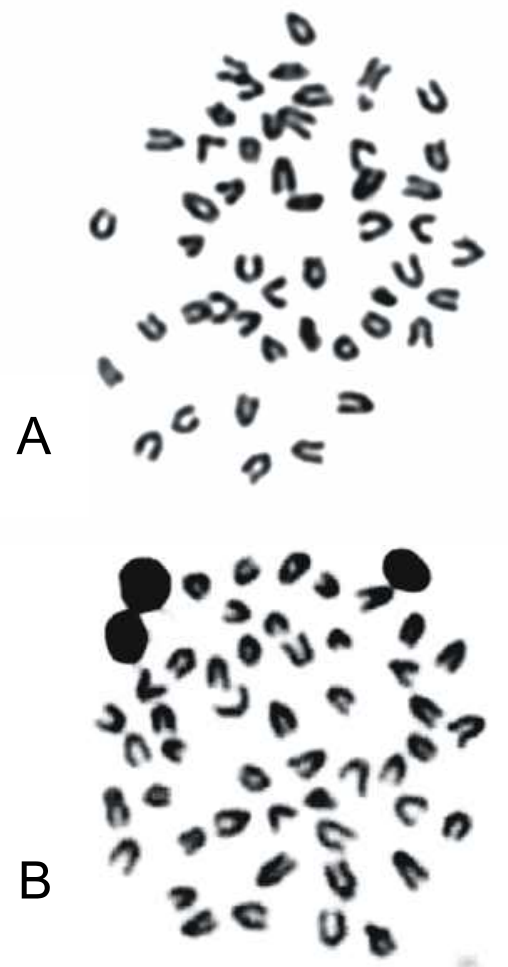

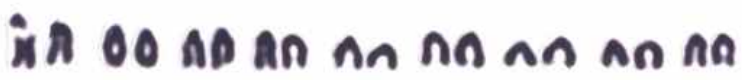
ae no aA an on DI a aA Da

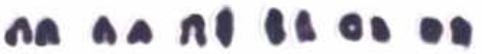

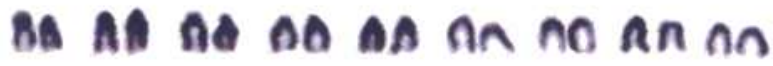
wh or a ha ma an on aA Da

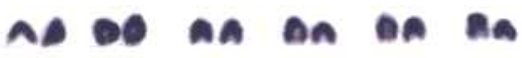

Fig. 5. Metaphase and idiogram of Oryzias dancena (A) and O. javanicus (B). All scale Bar indicates $10 \mu \mathrm{m}$.

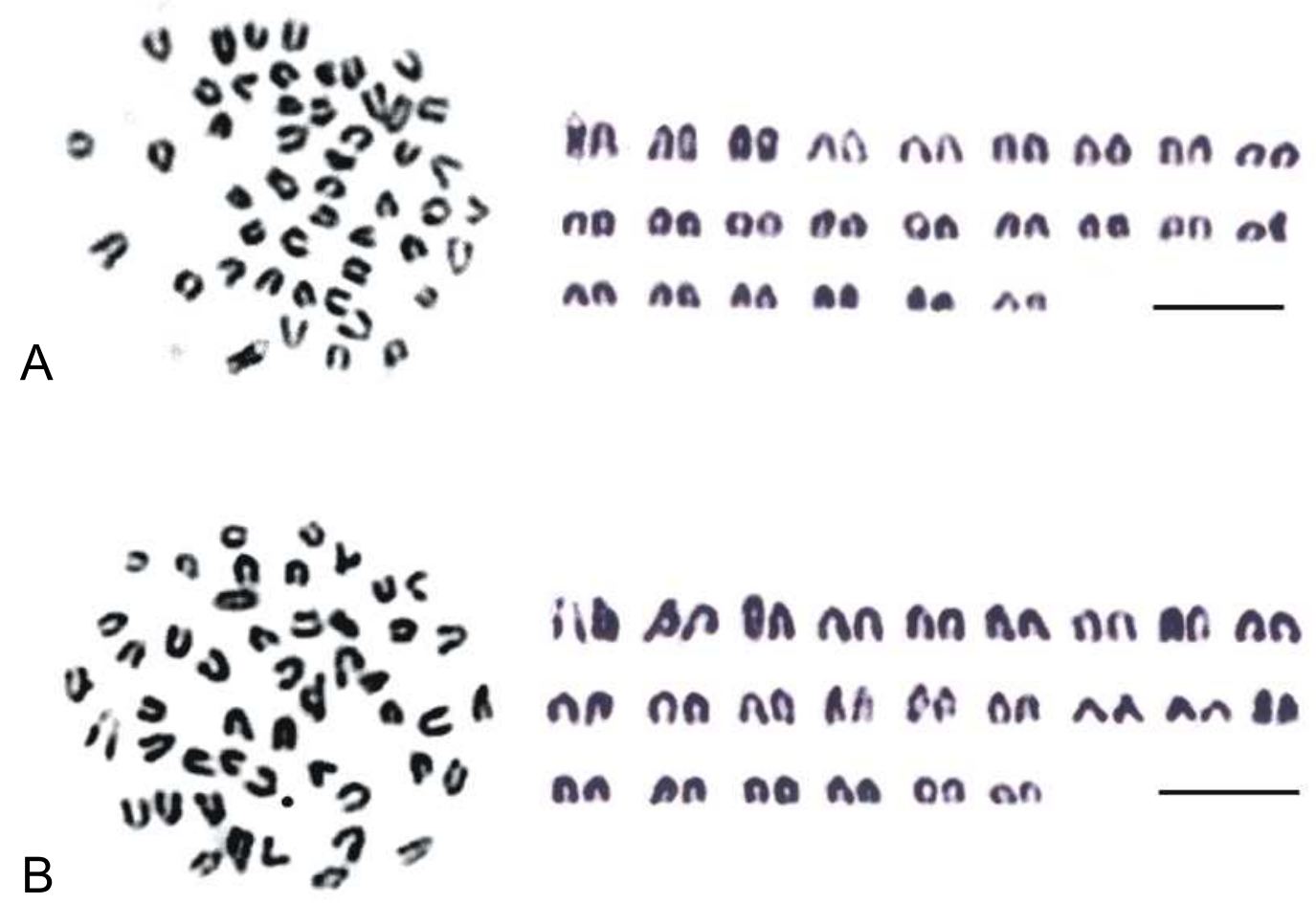

Fig. 6. Metaphase and idiogram of hybrid between Oryzias dancena and O. javanicus. (A) ODJ: O. dancena ( $\$$ ) x O. javanicus $\left(O^{\prime}\right)$. (B) OJD: O. javanicus $($ O $)$ x $O$. dancena $\left(O^{7}\right)$. All scale Bar indicates $10 \mu \mathrm{m}$. 
Table 9. Sex ratios of Oryzias dancena (OD), O. javanicus (OJ) and their hybrids (ODJ and OJD) by histological analysis of gonads

\begin{tabular}{|c|c|c|c|c|}
\hline Group & $\begin{array}{c}\text { No. of fish } \\
\text { Analyzed } \\
\text { (morphological sex) }\end{array}$ & Female (\%) & $\begin{array}{c}\text { Male } \\
(\%)\end{array}$ & $\begin{array}{l}\text { Intersex } \\
(\%)\end{array}$ \\
\hline OD & $\begin{array}{c}30 \\
(+\circ: 15, \text { 刃:15) }\end{array}$ & 50.0 & 50.0 & 0.0 \\
\hline OJ & $\begin{array}{c}30 \\
(\text { 우:15, d:15) }\end{array}$ & 50.0 & 50.0 & 0.0 \\
\hline ODJ & $\begin{array}{c}30 \\
\left(+9: 15,8^{2}: 15\right)\end{array}$ & 3.3 & 90.0 & 6.7 \\
\hline OJD & $\begin{array}{c}16 \\
\left(ㅇ: 8,8^{1}: 8\right)\end{array}$ & not identified & 31.3 & 6.3 \\
\hline
\end{tabular}

(oligospermia)인 것으로 나타났다. OJD의 경우 형태학적으로 암수인 개체를 각각 8 마리씩 조사한 결과 암컷의 형태를 지닌 개체에서 간성인 개체가 나타났다. 수컷 생식소를 가진 개체 는 5 마리 $(31.3 \%)$ 였으며, 1 마리( $6.3 \%)$ 는 간성으로 나타났고, 나머지 10마리 (62.4\%)에서는 조직학적으로 생식소를 관찰하 지 못했다.

\section{고 찰}

본 연구에서 바다송사리, 자바송사리, 이들 두 종 간 잡종 $(\mathrm{ODJ})$ 및 상반잡종 $(\mathrm{OJD})$ 의 난발생을 조사한 결과 $\mathrm{ODJ}$ 와 OJD 모두 각각 모계로 사용된 바다송사리 및 자바송사리와 유사한 난발생 과정을 거치며, 난발생 속도는 모계를 따르는 것으로 나타났다. 이전 Oryzias 속 잡종의 난발생을 조사한 연구로는 O. melastigma와 자바송사리, O. latipes와 자바송사 리 그리고 O. latipes와 O. melastigma의 잡종과 상반잡종의 보고가 있었으며 (Hori and Iwamatsu, 1996), O. latipes와 $O$. celebensis의 잡종과 상반 잡종의 연구가 있었다 (Iwamatsu et al., 1984). 그러나 이들 연구 모두 난발생 과정 중 상실기 (morula stage), 배체 형성기 (embryonic body stage)와 안포 형성기 (optic vesicle stage) 시기의 폐사율에 대한 연구만 있을 뿐 본 연구와 같이 잡종의 난발생 과정 시간을 비교한 것은 보고된 바 없다. 이전의 연구에서 잉어류 두 종 (common carp Cyprinus carpio, mrigal Cirrhinus mrigala)의 잡종과 상반 잡종 의 난발생 연구 결과 난발생 초기에 발생 속도가 common carp, common carp x mrigal, mrigal x common carp 그리고 mrigal의 순으로 나타났으나, 이후 부화시기에는 mrigal이 가 장 먼저 도달했으며, 다음으로 mrigal x common carp, common carp x mrigal, 그리고 common carp가 가장 늦게 도달하여 잡종군들의 난발생 시기가 친어의 중간 형질을 나타냄이 보고 된 바 있다 (Gupta et al., 1986). 또한, Epinephelus costae 암컷과 E. marginatus 수컷의 잡종을 유도한 연구에서는 잡종군의 발생 시간과 부화 시기가 친어군들 보다 더 빨리 진행되는 것으로 나타났다 (Glamuzina et al., 1998; 2001). 앞으로 Oryzias 속의 종 간 난발생 과정의 형태와 시간의 비교 연구도 이루어 져 본 연구 결과와 비교할 필요가 있을 것으로 생각된다.
잡종의 수정률은 사용된 종간의 진화학적 유연관계에 따라 크게 좌우된다 (Ari, 1988). Takehana et al. (2005)은 Oryzias 속 중 13종을 대상으로 하여 미토콘드리아 DNA (mtDNA)를 이용한 계통분류학적 분석을 실시하여 3 개의 단계통 (monophyletic species) 그룹인 latipes 그룹, javanicus 그룹 및 celebensis 그룹으로 나누었다. 본 실험에서 유도된 ODJ와 $\mathrm{OJD}$ 의 수정률은 각각 $89.4 \%$ 와 $81.8 \%$ 로 친어군으로 사용된 바다송사리 (97.3\%) 및 자바송사리 $(92.3 \%)$ 의 수정률과 유사 하였으며 같은 javanicus 그룹에 속해 유연관계가 높았다. $O$. latipes와 O. luzonensis의 잡종 (Iwamatsu et al., 1994)의 경우에 도 수정율이 높게 나타났는데 이들 두 종이 mtDNA 분석 시 같은 latipes 그룹에 속해 계통 분류 상 유연관계가 높았다. 이와 다르게 O. latipes와 O. celebensis 잡종의 수정률은 $79.2 \%$ 로 친어군 보다 낮게 나타났으며 (Iwamatsu et al., 1984), 이들 두 종은 계통 그룹에서 latipes 그룹과 celebensis 그룹으로 유연 관계가 적었으며, O. celebensis와 자바송사리의 잡종과 상반 잡종에서도 수정률이 각각 $61.2 \%$ 와 $75.2 \%$ 로 모두 친어군보다 낮은 수정률을 나타내었고 (Iwamatsu et al., 1994), 각각 celebensis 그룹과 javanicus 그룹에 속하여 진화적으로 유연관 계가 적은 것으로 나타났다.

바다송사리와 자바송사리 및 잡종군들의 부화율을 조사한 결과 바다송사리가 $93.4 \%$ 로 가장 높게 나타났으며, 자바송사 리가 $80.3 \%$ 로 잡종인 ODJ $(80.2 \%)$ 와 유사하게 나타났다. 하지 만 $\mathrm{OJD}$ 의 경우 부화율이 $7.4 \%$ 로 친어군과 $\mathrm{ODJ}$ 에 비하여 현저 히 낮게 나타났다. 이전의 연구에서 자바 송사리와 $O$. $m e l a s t i g m a$ 의 잡종의 부화율이 $7.0 \%$ 로 친어군과 $O$. melastigma와 자바 송사리의 잡종보다 현저히 낮게 나타남이 보고된 바 있어 (Iwamatsu et al., 1986), 본 실험과 유사하게 상반잡종군의 부화율이 친어군과 잡종군보다 현저히 낮게 나타났다. 이는 자바송사리를 모체로 교배를 유도하였을 때 난발생이 제대로 이루어지지 않아 부화율이 현저히 낮아지는 것으로 생각되며, 앞으로 자바송사리와 다른 종과의 잡종 유 도 및 염색체 분열상이나 분자생물학적 분석을 통한 연구가 필요할 것으로 사료된다. 또한, O. latipes와 자바송사리 간의 잡종군과 O. latipes와 O. melastigma 간의 잡종들은 모두 폐사 하였다고 보고되었다 (Iwamatsu et al., 1994). 이는 O. latipes와 두 종 (자바송사리, O. melastigma)이 진화학적으로 바다송사 리와 자바송사리 간의 관계보다 유연관계가 더 멀기 때문인 것으로 부화율도 수정율과 같이 종간의 진화학적 유연관계에 따라 차이가 나타나는 것으로 생각된다.

바다송사리와 자바송사리 및 그들의 잡종군의 기형률 조사 결과 $\mathrm{ODJ}$ 는 $10.6 \%$ 로 나타났고, $\mathrm{OJD}$ 는 $90.5 \%$ 가 모두 기형으 로 나타나 높은 기형률을 보였다. 이전의 O. latipes의 척추 기형에 대한 보고에서 척추 만곡이 발생하는 이유는 변형 유전자가 발현하였기 때문이라고 하였으며, 척추와 체절 간의 불균형적 발달로 인해 전장이 친어군 보다 짧은 만곡 기형 개체가 발생되는 것이라고 Takeuchi (1960)는 보고한 바 있다. 이 변형 유형은 본 실험에서 나타난 척추 변형과 그 형태가 거의 일치하고 있어 잡종군에서의 척추기형도 두 친어군의 
척추형성 과정 중 변형 유전자가 발현되기 때문인 것으로 추측된다.

역교배체를 유도한 연구는 이전의 보고에서 미꾸리 Misgurnus anguillicaudatus와 유도된 잡종 (미꾸라지 $M$. mizolepis x 미꾸리) 간의 역교배체를 유도하였을 때, 미꾸리 군에 비하여 높은 초기 생존율을 나타내었으며, 친어 암수의 중간 성질의 성장율을 보인다고 보고되었다 (Park et al., 1997). 또한, 무지개 송어 Oncorhynchus mykiss와 유도된 잡종 (무지 개 송어 $\mathrm{x}$ 컷스로트 송어 O. clarki bouvieri) 간의 역교배체가 $\mathrm{IHN}$ 바이러스에 저항성이 있다는 연구가 보고된 바 있다(Palti et al., 2001). 하지만 본 연구에서 바다송사리 (우)와 ODJ (O') 의 교배를 통해 역교배체를 유도하였으나 수정 후 3 일만에 모든 수정난이 폐사하여 ODJ가 수정 능력은 있으나 난발생이 이루어지지 않아 앞으로 이들 역교배체 수정란의 폐사 원인을 더 연구해야 할 것으로 생각한다.

어류의 세포 유전학적 분석에서 적혈구 세포 및 핵의 크기 조사는 그 측정 방법이 용이하여 배수체의 판단 기준 및 잡종 의 세포 유전학적 특징을 밝히는데 유용하게 사용되고 있다 (Benfey, 1989). 참돔 (우) x 감성돔 (O) 간의 잡종 (Park et al., 2004), 잉어와 붕어 간의 잡종 (Nam, 1998) 등의 연구에서 잡종 개체의 적혈구 세포 및 핵의 크기가 양친의 중간치를 나타내는 것으로 보고된 바 있다. 그러나 ODJ의 경우 적혈구 세포 및 핵의 크기를 ANOVA로 검정한 결과 부계인 자바송사 리의 형질과 유사한 것으로 나타났다 $(P<0.05)$. NORs은 세포 분화 과정 중 활성도가 변함에 따라 전사의 활성도도 영향을 받아 종 간, 개체 간, 세포 간에 다양한 양적 변이 양상이 있으며 (Derenzini, 2000), 2배체 interphase stage에서 적혈구 세포의 NORs가 통상 1 2개 나타난다고 보고되고 있다 (Phillips and Ihssen, 1985). 본 연구에서도 적혈구의 NORs 조사 결과 바다송사리와 자바송사리 간 구분 없이 1 2개의 적혈구 NORs/cell이 높은 빈도로 관찰되었다.

Oryzias 속의 염색체 분석은 이전의 보고에서 Uwa et al. (1986)이 염색체 분석 방법을 이용하여 3 종류의 염색체 그룹 으로 나눈 바 있다. Oryzias 속 중 12종의 염색체 핵형을 분석하 여 차간부 염색체와 차단부동원체 염색체로 이루어진 바다송 사리, 자바송사리, $O . h u b b s i$ 의 'monoarmed 그룹'과 중부 염색 체와 차중부 염색체로 이루어진 O. latipes, O. curvinotus, $O$. luzonensis, O. mekongensis의 'biarmed 그룹'으로 나누었다. 그리고 1 - 4쌍의 큰 중부 염색체나 차중부 염색체를 가지는 O. celebensis, O. marmoratus, O. matanensis, O. nigrimas 인 'fused 염색체 그룹'으로 나누었다. 이후 Naruse (1996)는 $\mathrm{mtDNA}$ 를 이용한 계통분류를 한 결과 이들 세 그룹을 지지하 는 연구결과를 보고하였으며 이후 Takehana et al. (2005)이 나눈 3 개의 단계통 (monophyletic species) 그룹인 latipes 그룹, javanicus 그룹 및 celebensis 그룹 역시 이전 연구와 같은 그룹 으로 나뉘었다. Javanicus 그룹에 속하는 바다송사리와 자바송 사리의 염색체 핵형 분석 결과 이전의 보고와 같은 결과를 나타내었다 (Uwa et al., 1986). 진화적인 관점에서 보았을 때, 이전의 연구에서 latieps 그룹의 O. latipes, javanicus 그룹의
자바송사리 및 celebensis 그룹의 O. celebensis를 대상으로 염 색체 핵형을 분석한 결과 O. latipes와 O. celebensis는 위성 (satellite) 차중부 염색체를 가지고 있으나, 자바송사리는 차단 부동원체 염색체에 2차 협착 부위를 가지고 있는 것으로 보고 되었으며, O. celebensis는 $2 \mathrm{n}=36$ 으로 염색체 수는 적으나 염색 체의 크기가 커서 이들 염색체가 Robertsonian 결합으로 인해 형성된 것으로 생각되어 자바송사리와는 다른 진화된 형태의 핵형을 가지고 있다고 보고되었다 (Uwa et al., 1986). 또한, 경골어류의 대부분은 $2 n=48$ 의 차단부동원체 염색체 $(\mathrm{NF}=48)$ 를 가지는 것이 핵형의 기본형으로 알려져 있어, 자바송사리 가 O. latipes와 O. celebensis 보다 원형에 가까운 핵형을 가지 고 있다고 보고하였다 (Uwa and Iwata, 1981). 본 실험의 바다 송사리 역시 자바송사리와 유사한 염색체 핵형을 가지고 있어 latipes 그룹과 celebensis 그룹 보다 javanicus 그룹에 속하는 종들이 핵형의 기본형을 가지는 진화가 늦은 그룹으로 사료된 다. 성염색체 (sex chromosome)에 있어 본 실험 결과 바다송사 리와 자바송사리 모두 암.수간 염색체 이형현상이 관찰되지 않았으나, fluorescence in situ hybridization (FISH)법을 이용한 연구에서 바다송사리의 수컷 염색체인 $\mathrm{Y}$ 염색체가 한 쌍의 차단부동원체 염색체의 중간에 발현하는 것을 확인하여 암.수 간 염색체 차이를 밝혀내었다 (Takehana et al., 2007b). $O$. latipes와 바다송사리는 $\mathrm{XX} / \mathrm{XY}$ 로 같은 성결정 기작을 가지지 만, O. latipes의 성결정 유전자 (sex determination gene)로 밝혀 진 DMY (the DM-domain gene on the Y chromosome) 유전자는 바다송사리에서 성결정 유전자로 확인되지 않아 (Takehana et al., 2007b) 앞으로 바다송사리의 성결정 유전자를 밝히는 일이 척추동물의 성결정 메커니즘의 진화를 밝히는데 있어서 매우 중요한 연구가 될 것으로 생각된다.

성비 조사를 위해 바다송사리, 자바송사리 그리고 잡종군 들의 성비를 형태학적으로 조사한 결과 바다송사리와 자바송 사리는 암수 성비가 거의 $1: 1$ 의 비율로 나타났으며, 이는 생식 소를 조직학적으로 분석한 결과와 일치하였다. 하지만, ODJ 의 성비를 조직학적 분석 방법으로 조사한 결과 수컷이 $90.0 \%$ 로 수컷의 비율이 매우 높게 나타났다. 이전의 연구에서 $O$. curvinotus와 O. latipes의 잡종을 유도한 결과 형태학적으로 수컷인 개체를 조직학적으로 분석 시 $21 \%$ 가 암컷인 것으로 보고되었으며, O. latipes와 O. curvinotus의 잡종에서는 형태학 적으로 수컷인 개체의 $100 \%$ 가 암컷인 것으로 밝혀졌다 (Shinomiya et al., 2006). 이는 이 두 종의 성결정 유전자로 알려진 $\mathrm{DMY}$ 유전자가 친어로 사용된 암컷의 $\mathrm{X}$ 염색체와 수컷의 $\mathrm{Y}$ 염색체가 잡종군 수컷의 $\mathrm{XY}$ 염색체를 구성하면서 기원이 다른 $\mathrm{DMY}$ 유전자가 잡종 개체에서 낮은 수준으로 발현되거나 발현되지는 않기 때문인 것으로 보고되었다 (Shinomiya et al., 2006). 본 연구에서 사용된 바다송사리와 자바송사리의 경우 성결정 기작이 $\mathrm{XX} / \mathrm{XY}$ 와 $\mathrm{ZZ/ZW}$ 로 서로 다르며 (Takehana et al., 2007b; 2008), 성결정 유전자가 아직 밝혀져 있지 않다. 본 연구에서 ODJ의 수컷 비율이 $90 \%$ 로 암컷에 비하여 현저하게 높게 나타나는 것으로 보아, 잡종 유도시 암컷이 유도되는 이전의 연구 결과와는 상반되게 수컷 
을 유도하는 성결정 유전자의 발현율이 높게 발현되는 것으로 사료된다. $\mathrm{OJD}$ 의 성비는 조직학적 분석시 간성이 $6.3 \%$, 수컷 이 $31.3 \%$ 로 나타났고, 나머지 $62.4 \%$ 에서는 조직학적 방법으 로는 생식소를 관찰하지 못하였다. 성비뿐만 아니라 부화율도 $7.44 \%$ 로 대부분의 OJD 개체가 폐사하는 것으로 보아, 이는 자바송사리 암컷의 ZW와 바다송사리 수컷의 XY 염색체에서 각각의 염색체가 조합될 때에 성결정 유전자뿐만 아니라 염색 체 분열이 비정상적으로 분열하기 때문인 것으로 생각된다. 최근의 연구에서 근연종인 $O . h u b b s i$ 와 바다송사리가 서로 다른 $\mathrm{ZZ/ZW}$ 와 $\mathrm{XX} / \mathrm{XY}$ 성결정 기작을 가지고 있으며, $\mathrm{ZW}$ 와 $\mathrm{XY}$ 성염색체가 서로 다른 기원을 가져 이들 두 종의 성염색체 가 상동성을 가지지 않는다고 보고된 바 있다 (Takehana et al., 2007a). 또한, O. hubbsi와 자바송사리가 동일한 $\mathrm{ZZ/ZW}$ 성 결정 기작을 가지지만, 성 염색체가 상동성을 가지지 않아, 이들 두 종의 성결정 유전자가 다른 것으로 사료된다고 보고 되었다 (Takehana et al., 2008). 따라서 앞으로 이들 종의 성결 정 유전자를 찾는 연구 뿐만 아니라, OJD 개체의 염색체 분열 상에 대한 연구가 이루어져야 할 것이다.

본 연구에서는 바다송사리와 자바송사리의 잡종을 유도하 여 불임 개체군을 생산하였으며, 그 잡종 개체의 생물학적 분석을 수행하였다. 앞으로 본 잡종 개체를 해양생태계위해성 평가를 하는데 있어 유용한 모델로 활용할 수 있을 것으로 생각된다.

$$
\text { 사 사 }
$$

본 연구는 국토해양부 해양환경복원기술개발사업 (과제번 호20088033-1)의 지원에 의해 수행되었습니다.

\section{참고문헌}

Ari K. 1988. Viability of allotriploids in salmonids. Bull Jap Soc Sci Fish 54, 1695-1701.

Benfey TJ. 1989. A bibliography of triploid fish, 1943 to 1988. Can Tech Rep Fish Aquat Sci 1682, 33.

Cho YS, Lee SY, Kim DS and Nam YK. 2010. Tolerance capacity to salinity changes in adult and larva of Oryzias dancena, a euryhaline medaka. Kor J Ichthyol 22, 9-16.

Derenzini M. 2000. The AgNORs. Micron 31, 117-120. Glamuzina B, Glavi N, Skaramuca B, Koul V and Tutman P. 2001. Early development of the hybrid Epinephelus costae $q$ x E. marginatus $\hat{\sigma}$. Aquaculture 198, 55-61.

Glamuzina B, Skaramuca B, Glavi N and Koul V. 1998. Egg and larval development of the dusky grouper, Epinephelus marginatus (Lowe, 1834). Sci Mar 62, 373-378.

Gupta SD, Khan HA, Reddy PVGK and Kowtal GV. 1986. Studies on the intergenetic hybrid, common carp, Cyprinus carpio communis L. $\mathrm{x}$ mrigal, cirrhinus mrigala (Hamilton). Establishment of a Network of Aquaculture Centres in Asia project reports, FAO Fisheries \& Aquaculture, 1-10.

Hori R and Iwamatsu T. 1996. Experiments on interspecific hybridization among Oryzias melastigma, Oryzias javanicus and Oryzias latipes. Bull Oraki Women's College 37, 1-6.

Inoue $\mathrm{K}$ and Takei Y. 2003. Asian medaka fishes offer new models for studying mechanisms of seawater adaptation. Comp Biochem Physiol B 136, 635-645.

Iwamatsu T, Kobayashi H, Yamashita M, Shibata Y and Yusa A. 2003. Experiments hybridization among Oryzias species. II. Karyogamy and abnormality of chromosome separation in the cleavage of interspecific hybrids between Oryzias latipes and $O$. javanicus. Zool Sci 20, 1381-1387.

Iwamatsu T, Mori T and Hori R. 1994. Experimental hybridization among Oryzias species I. O. celebensis, $O$. javanicus, $O$. latipes, $O$. luzoenesis and $O$. melastigma. Bull Aichi Univ of Edu 43, 103-112.

Iwamatsu T, Watanabe T, Hori R, Lam TJ and Saxena OP. 1986. Experiments on interspecific hybridization between Oryzias melastigma and Oryzias javanicus. Zool Sci 3, 287-293.

Iwamatsu T and Hirata K. 1984. Normal course of development of the Java medaka, Oryzias javanicus. Bull Aichi Univ Edu 33, 87-109.

Iwamatsu T, Uwa H, Inden A and Hirata K. 1984. Experiments on interspecific hybridization between Oryzias latipes and Oryzias celebensis. Zool Sci 1, 653-663.

Kakuno A, Fujii K and Koyama J. 2001. Histological studies on the gonadal development in Java medaka (Oryzias javanicus). Bull Fish Res Agen 1, 35-37.

Kim DS, Nam YK and Park IS. 1995a. Performance of diploid and triploid hybrid loach, Misgurnus mizolepis female $\times M$. anguillicaudatus male. Aquaculture 137, 326-327.

Kim KK, Bang IC, Kim Y and Kim DS. 1995b. Survival and growth in larval stage of induced hybrid between olive flounder (Paralichthys olivaceus) and spotted flounder (Verasper variegatus). J Aquaculture 8, 69-76.

Kim IS and Kim SY. 1993. Interspecific Hybridization between Oryzias sinensis and $O$. latipes from Korea. Kor J Ichthyol 5, 113-121.

Kim DS, Park EH and Kim JS. 1982. Karyotypes of nine species of the Korean catfihses (Teleostomi: Siluriformes). Kor J Genet 4, 57-68. 
Lemoine HL Jr and Smith LT. 1980. Polyploidy induced in brook trout by cold shock. Trans Fish Soc 109, 626-631.

Li J, Zhang Q, Qi J, Wang X and Wang Z. 2006. Embryonic and larval development in hybrid between Paralichthys olivaceus (female) and Verasper variegates (male). J Fish Sci China 13, 732-739.

Nam YK. 1998. Cytogenetic analysis of induced hybrid between common carp (Cyprinus carpio) and crucian carp (Carassius auratus). J Aquaculture 1, 77-81.

Naruse K. 1996. Classification and phylogeny of fishes of the genus Oryzias and its relatives. Fish Biol J Medaka 8, 1-9.

Nelson JS. 2006. Fishes of the World. 4th edition, Wiley \& Sons Inc, New York, U.S.A. 276-277.

Palti Y, Nochols KM, Waller KI, Parsons JE and Thorgaard GH. 2001. Association between DNA polymorphisms tightly linked to MHC class II genes and IHN virus resistance in backcrosses of rainbow and cutthroat trout. Aquaculture 194, 283-289.

Park IS, Kim BS, Hur JW, Iraida GS, Kim DS, Im JH and Park IS. 2004. Cytogenitic analysis of an artificial Red (ㅇ) Black seabream (ð) Hybid. Kor J Genet 26, 283-288.

Park IS, Nam YK, Douglas SE, Johnson SC and Kim DS. 2003. Genetic characterization, morphometrics and gonad development of induced interspecific hybrids between yellowtail flounder, Pleuronectes ferruginesu (Storer) and winter flounder, Pleuronectes americanus (Walbaum). Aquacult Res 34, 389-396.

Park IS, Kim BS, Im JH, Park HM, Nam YK, Jeong CH and Kim DS. 1997. Improved early survival in backcrosses of male mud loach (Misgurnus mizolepis) $\mathrm{x}$ cyprinid loach (M. anguillicaudatus) hybrid to female cyprinid loach. J Aquaculture 10, 363-371.

Park IS, Kim PK, Kim JM, Choi GC and Kim DS. 1996. Production of hybrid and allotriploid between rainbow trout (Oncorhynchus mykiss) and coho Salmon (O. kisutch). J Aquaculture 9, 133-140.

Phillips RB and Ihssen PE. 1985. Chromosome banding in salmonid fishes; nucleolar organizer regions in Salmo and Salvelinus. Can J Genet Cytol 27, 433-440.

Robert TR. 1998. Systematic observations on tropical Asian medakas or ricefishes of the genus Oryzias, with descriptions of four new species. Ichthyol Res 45, 213-224.

Sakai C, Konno F, Nakani O, Iwai T, Yokota T, Lee
J, Nishida-Umehara C, Kuroiwa A, Matsuda Y and Yamashita M. 2007. Chromosome elimination in the interspecific hybrid medaka between Oryzias latipes and O. hubbsi. Chromosome Research 15, 697-709.

Sezaki K and Kobayashi H. 1978. Comparison of erythrocytic size between diploid and tetraploid in spinous loach, Cobitis biwae. Bull Jap Soc Sci Fish $41,851-854$.

Shinomiya A, Kato M, Yaezawa M, Sakaizumi M and Hamaguchi S. 2006. Interspecific hybridization between Oryzias latipes and Oryzias curvinotus causes XY sex reversal. J Exp Zoolo 305, 890-896.

Song HY, Bang IC, Nam YK and Kim DS. 2009a. Early gonadogenesis and sex differentiation of a marine medaka, Oryzias dancena (Beloniformes; Teleostei). Kor J Ichthyol 21, 141-148.

Song HY, Bang IC, Nam YK and Kim DS. 2009 b. Embryogenesis and early ontogenesis of a marine medaka, Oryzias dancena. Kor J Ichthyol 21, 227-238.

Susuki N and Hibiya T. 1984. Development of eggs larvae of two bitterlings, Rhodeus atremius and R. suigensis (Cyprinidae). Jap J Ichthyol 31, 287-296.

Takehana Y, Hamaguchi S and Sakaizumi M. 2008. Different origins of $\mathrm{ZZ} / \mathrm{ZW}$ sex chromosomes in closely related medaka fishes, Oryzias javanicus and O. hubbsi. Chromosome Research 16, 801-811.

Takehana Y, Naruse K, Hamaguchi S and Sakaizumi M. 2007a. Evolution of ZZ/ZW and XX/XY sex-determination systems in the closely related medaka species, Oryzias hubbsi and O. dancena. Chromosoma 116, 463-470.

Takehana Y, Demiyah D, Naruse K, Hamaguchi S and Sakaizumi M. 2007b. Evolution of different Y chromosomes in two medaka species, Oryzias dancena and $O$. latipes. Genetics 175, 1335-1340.

Takehana Y, Naruse K and Sakaizumi M. 2005. Molecular phylogeny oh the medaka fishes genus Oryzias (Beloniformes: Adrianichthyidae) based on nuclear and mitochondrial DNA sequences. Mol Phylohenet Evol 36, 417-428.

Takeuchi K. 1960. A study of the mutant (wavy) in medaka, Oryzias latipes. Annot Zool Japon 33, 124-131.

Uwa H, Uyeno T, Arai R, Taniuchi T and Sakaizumi M. 1986. Karyotype evolution and geographical distribution in the ricefish, genus Oryzias (Oryziidae) Indo-Pacific fish biology: proceedings of the second international conference on Indo-Pacific fishers. 
Ichthyological Society of Japan, Tokyo, 867-876.

Uwa H and Iwata A. 1981. Karyotype and cellular DNA content of Oryzias javanicus (Oryziatidae, Pisces). Chromosome Inf Serv 31, 24-26.

2010년
6월 28일 접수
2010년
8월 10월 11일 수성리

